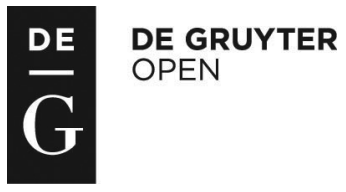

\title{
THE EFFECT OF DIFFERENT DIETARY LEVELS AND SOURCES OF METHIONINE ON THE GROWTH PERFORMANCE OF TURKEYS, CARCASS AND MEAT QUALITY*
}

\author{
Daria Murawska ${ }^{1 \bullet}$, Magdalena Kubińska², Michał Gesek³, Zenon Zduńczyk ${ }^{4}$, Urszula Brzostowska', \\ Jan Jankowski \\ ${ }^{1}$ Department of Commodity Science and Animal Improvement, Faculty of Animal Bioengineering, \\ University of Warmia and Mazury in Olsztyn, Oczapowskiego 5, 10-719 Olsztyn, Poland \\ ${ }^{2}$ Department of Poultry Science, Faculty of Animal Bioengineering, \\ University of Warmia and Mazury in Olsztyn, Oczapowskiego 5, 10-719 Olsztyn, Poland \\ ${ }^{3}$ Department of Pathological Anatomy, Faculty of Veterinary Medicine, \\ University of Warmia and Mazury in Olsztyn, Oczapowskiego 13, 10-719 Olsztyn, Poland \\ ${ }^{4}$ Institute of Animal Reproduction and Food Research of the Polish Academy of Sciences, \\ Tuwima 10, 10-748 Olsztyn, Poland \\ •Corresponding author: daria.murawska@uwm.edu.pl
}

\begin{abstract}
The aim of this study was to determine the effect of different dietary levels and sources of methionine (Met) on the growth performance of turkeys, carcass and meat quality. A total of $816 \mathrm{Hybrid}$ Converter turkeys in 6 groups and 8 replications were fed wheat-soybean meal-based diets supplemented with three sources of Met: DL-isomer, L-isomer and DL-hydroxy analog (DLM, LM and MHA, respectively). In four 4-week periods (from 1 to 16 weeks of age), the Met content of turkey diets corresponded to the level recommended by NRC (1994) or was increased by approximately $50 \%$ to match the intake recommended by some breeding companies. Increased dietary Met content resulted in a higher final body weight $(\mathrm{BW})$ of turkeys $(\mathrm{P}=\mathbf{0 . 0 0 2})$ and a lower feed conversion ratio (FCR) $(\mathrm{P}=\mathbf{0 . 0 4 9})$, but had no effect on carcass dressing percentage and most parameters of carcass quality. The higher dietary Met level contributed to a decrease in meat $\mathrm{pH}$, a lower contribution of redness and a smaller muscle fiber diameter $(P=0.028, P=0.040$ and $P=0.004$, respectively). The higher dietary Met level had no influence on the redox status of meat, but it reduced the incidence of lymphoid cell infiltration between muscle fibers threefold $(\mathrm{P}=\mathbf{0 . 0 0 3})$. Throughout the experiment, no significant differences were noted in the growth performance parameters of turkeys, irrespective of Met source. MHA contributed to higher abdominal fat content, lower dry matter (DM) content and lower catalase (CAT) activity in breast meat, compared with DLM and LM. Increased dietary Met content, approximately $50 \%$ higher than that recommended by NRC (1994), regardless of Met source, led to higher final BW of turkeys, but had no effect on carcass dressing percentage and most parameters of carcass quality.
\end{abstract}

Key words: turkeys, methionine, growth performance, carcass quality, meat quality

*This work was supported by the National Science Centre, Grant No. 2013/11/B/NZ9/02496. The authors would like to thank the technical staff involved in the feeding experiment and meat quality evaluation. 
Similarly to broiler chickens, significant genetic progress has been observed over recent years also in turkeys with respect to both growth rate and feed efficiency. It is currently estimated that turkeys are marketed in about half the time and at about twice the body weight (BW) compared to 50 years ago (Havenstein et al., 2007). However, as shown by numerous studies, the selection of birds for greater BW or muscle development has also negative consequences such as histological and biochemical modifications of the muscle tissue by impairing some meat quality traits (Damaziak et al., 2016). Turkeys need adequate nutrition to realize their full growth potential and produce high-quality meat (Wu et al., 2011). Sulfur amino acids (SAA), in particular the essential amino acid (AA) methionine (Met), are important determinants of the biological value of protein in poultry diets. Typical wheat-soybean meal-based diets for growing turkeys, not supplemented with pure AA, contain only $0.3-0.4 \%$ of Met (Jankowski et al., 2014; Jankowski et al., 2016; Kubińska et al., 2016; Jankowski et al., 2017), i.e. much less than the value recommended by NRC (1994). For this reason, Met deficiency in feed raw materials has been compensated for by supplementing diets with feed-grade Met to meet the nutrient requirements of birds.

NRC (1994) recommendations have not been updated for more than 20 years, and today they are much lower than those of commercial breeding companies (BUT, 2012; Hybrid Turkeys, 2014). The findings of Lemme et al. (2005) suggest that the Met content of turkey diets should be higher than that recommended by NRC (1994). In other experiments (Jankowski et al., 2016; Kubińska et al., 2016), increased dietary Met levels, relative to NRC recommendations (1994), resulted in inconclusive findings. For many decades, poultry diets have been supplemented with feedgrade Met, mainly DL-methionine (DLM) (Willke, 2014). An alternative solution is to supplement poultry diets with DL-2-hydroxy-4-(methyl) butanoic acid (DLHMBA, MHA) or L-methionine (LM) as recently used in broiler chicken (Swennen et al., 2011; Shen et al., 2015) and turkey (Gonzales-Esquerra et al., 2007; Park et al., 2016) nutrition. LM is incorporated into body proteins, whereas DLM and MHA must be converted to LM in vivo. Shen et al. (2015) reported a better growth response of broiler chickens to LM. Another reason for using DLM substitutes is a beneficial influence of LM and MHA on the antioxidant status of birds, observed by some authors (Park et al., 2016; Swennen et al., 2011). Experiments involving broiler chickens have shown that dietary Met levels may affect carcass and meat quality (Drażbo et al., 2015). According to Wang et al. (2009), dietary Met content stabilizes meat color through inhibiting protein oxidation. On the other hand, Zhai et al. (2012) suggested that increased muscle protein deposition induced by Met supplementation could have been caused by sarcoplasm hypertrophy rather than myofibrillar hypertrophy. The available literature provides scant information on the quality of meat from turkeys fed diets with increased levels of different Met sources. The aim of this study was to determine the effect of different dietary levels and sources of Met on the growth performance, carcass and meat quality of turkeys. 


\section{Material and methods}

\section{Animal ethics}

The animal protocol used in this study was approved by the Local Ethics Committee (Olsztyn, Poland).

Table 1. Composition and nutrient concentrations in basal diets $\left(\mathrm{g} \mathrm{kg}^{-1}\right)$

\begin{tabular}{|c|c|c|c|c|}
\hline \multirow{2}{*}{ Item } & \multicolumn{4}{|c|}{ Feeding period (weeks) } \\
\hline & $1-4$ & $5-8$ & $9-12$ & $13-16$ \\
\hline \multicolumn{5}{|l|}{ Ingredients } \\
\hline wheat & 49.09 & 49.26 & 60.08 & 68.65 \\
\hline soybean meal & 41.65 & 40.56 & 28.84 & 19.97 \\
\hline soybean oil & 2.02 & 2.90 & 3.96 & 3.70 \\
\hline fish meal & 3.00 & - & - & - \\
\hline rapeseed meal & - & 3.00 & 4.00 & 5.00 \\
\hline sodium sulfate & 0.15 & 0.15 & 0.15 & 0.15 \\
\hline sodium chloride & 0.11 & 0.15 & 0.14 & 0.12 \\
\hline limestone & 1.41 & 1.46 & 0.87 & 0.76 \\
\hline monocalcium phosphate & 1.61 & 1.52 & 0.97 & 0.77 \\
\hline L-Lysine $\mathrm{HCl}$ & 0.38 & 0.41 & 0.39 & 0.32 \\
\hline L-Threonine & 0.08 & 0.09 & 0.10 & 0.06 \\
\hline vitamin-mineral premix ${ }^{1}$ & 0.50 & 0.50 & 0.50 & 0.50 \\
\hline \multicolumn{5}{|l|}{ Calculated nutritional value $(\%)$} \\
\hline metabolizable energy (kcal/kg) & 2750 & 2850 & 3050 & 3125 \\
\hline crude protein & 27.0 & 25.0 & 21.0 & 18.0 \\
\hline arginine & 1.71 & 1.59 & 1.29 & 1.07 \\
\hline lysine & 1.74 & 1.603 & 1.320 & 1.070 \\
\hline methionine & 0.40 & 0.34 & 0.29 & 0.26 \\
\hline methionine + cysteine & 0.84 & 0.76 & 0.66 & 0.60 \\
\hline threonine & 1.05 & 0.98 & 0.83 & 0.67 \\
\hline $\mathrm{Ca}$ & 1.20 & 1.10 & 0.75 & 0.65 \\
\hline $\mathrm{P}$ & 0.81 & 0.74 & 0.60 & 0.55 \\
\hline available $\mathrm{P}$ & 0.58 & 0.50 & 0.37 & 0.32 \\
\hline sodium & 0.15 & 0.13 & 0.12 & 0.11 \\
\hline
\end{tabular}

${ }^{1} 0.5 \%$ of the premix provided per $\mathrm{kg}$ of diet: vitamin $\mathrm{A}$ (all trans-retinol acetate) - $15000 \mathrm{IU}$, vitamin $\mathrm{D}_{3}$ (cholecalciferol) - $5000 \mathrm{IU}$, vitamin $\mathrm{E}$ (all-rac- $\alpha$-tocopheryl acetate) - $100 \mathrm{mg}$, vitamin $\mathrm{K}_{3}-4 \mathrm{mg}$, vitamin $\mathrm{B}_{1}-$ $5 \mathrm{mg}$, vitamin $\mathrm{B}_{2}-15 \mathrm{mg}$, vitamin $\mathrm{B}_{6}-6 \mathrm{mg}$, niacin $-100 \mathrm{mg}$, biotin $-0.35 \mathrm{mg}$, pantothenic acid - $32 \mathrm{mg}$, nicotinic acid $-100 \mathrm{mg}$, folic acid $-4 \mathrm{mg}$, choline chloride $-700 \mathrm{mg}, \mathrm{Mn}-100 \mathrm{mg}, \mathrm{Zn}-80 \mathrm{mg}, \mathrm{Fe}-60 \mathrm{mg}, \mathrm{Cu}-$ $20 \mathrm{mg}, \mathrm{I}-1.5 \mathrm{mg}, \mathrm{Se}-0.3 \mathrm{mg}, \mathrm{Ca}-1.07 \mathrm{~g}$.

\section{Birds, management and diets}

The birds were kept in $2 \times 2 \mathrm{~m}$ pens on litter in a building with a controlled environment. The temperature and lighting programs were consistent with the recommendations of Hybrid Turkeys (2014). The birds had free access to feed and water. The study was conducted on 816 day-old female Hybrid Converter turkey poults obtained from the Grelavi commercial hatchery in Kętrzyn (Poland), divided into 6 dietary treatments (with 8 replications per group and 17 birds per replication) dif- 
fering in Met sources and supplementation levels. The birds were fed isocaloric and isonitrogenous wheat-soybean meal-based pelleted diets (crumbles in weeks 1-4 weeks) with a low or high content of DLM, LM (Evonic Industries, Germany) or MHA (calcium salt of 2-hydroxy-4-(methyl) butanoic acid, yield 84\% DLM, Novus International, Inc.). The dietary Met content consistent with the recommendations of NRC (1994) was regarded as "low" (L), and the dietary Met content increased by approximately $50 \%$ to match the intake recommended by some breeding companies was regarded as "high" $(\mathrm{H})$. The final concentrations of Met and MHA in the diets were verified analytically at the National Laboratory for Feedingstuffs in Lublin (Poland). Methionine content was analyzed by ultra-performance liquid chromatography with UV detection (UPLC-UV), and MHA content was determined by high-performance liquid chromatography with fluorescence detection (HPLC-FLD). The composition and calculated nutrient content of basal diets fed to turkeys in weeks 1-4, 5-8, 9-12 and 13-16 are shown in Table 1. The amount of supplemental Met and the total Met content of experimental diets, determined analytically, are given in Table 2.

Table 2. Methionine (Met) content of experimental diets

\begin{tabular}{|c|c|c|c|c|}
\hline \multirow{2}{*}{ Item } & \multicolumn{4}{|c|}{ Feeding period (weeks) } \\
\hline & $1-4$ & $5-8$ & $9-12$ & $13-16$ \\
\hline Basal diet (\%) & 0.43 & 0.40 & 0.30 & 0.27 \\
\hline \multicolumn{5}{|c|}{ Expected content of Met in the $\operatorname{diet}^{1}(\%)$} \\
\hline lower (control) Met level ${ }^{2}$ & 0.55 & 0.45 & 0.36 & 0.32 \\
\hline higher (experimental) Met level ${ }^{3}$ & 0.77 & 0.67 & 0.56 & 0.50 \\
\hline \multicolumn{5}{|l|}{ Met content of the final $\operatorname{diet}^{4}(\%)$} \\
\hline $\mathrm{DLM}_{\mathrm{L}}$ & 0.58 & 0.46 & 0.37 & 0.34 \\
\hline $\mathrm{LM}_{\mathrm{L}}$ & 0.54 & 0.45 & 0.36 & 0.33 \\
\hline $\mathrm{MHA}_{\mathrm{L}}$ & 0.55 & 0.44 & 0.33 & 0.31 \\
\hline $\mathrm{DLM}_{\mathrm{H}}$ & 0.78 & 0.67 & 0.58 & 0.51 \\
\hline $\mathrm{LM}_{\mathrm{H}}$ & 0.82 & 0.67 & 0.56 & 0.50 \\
\hline $\mathrm{MHA}_{\mathrm{H}}$ & 0.79 & 0.64 & 0.52 & 0.49 \\
\hline
\end{tabular}

Sources of methionine (Met): DL-isomer (DLM), L-isomer (LM), DL-hydroxy analog (MHA), dosage of Met: "low" (L), "high" (H).

${ }^{1}$ MHA values were adjusted using a conversion factor of 1.19 .

${ }^{2} \mathrm{DLM}_{\mathrm{L}}, \mathrm{LM}_{\mathrm{L}}$ and $\mathrm{MHA}_{\mathrm{L}}$ treatments.

${ }^{3} \mathrm{DLM}_{\mathrm{H}}, \mathrm{LM}_{\mathrm{H}}$ and $\mathrm{MHA}_{\mathrm{H}}$ treatments.

${ }^{4} \mathrm{MHA}_{\mathrm{L}}$ and $\mathrm{MHA}_{\mathrm{H}}$ values were adjusted.

\section{Growth trial and sample collection}

Feed intake, BW and FCR were determined in weeks 1-4, 5-8, 9-12 and 13-16. Mortality rates were monitored throughout the experiment. At 112 days of age, after $12 \mathrm{~h}$ of fasting, 8 birds in each treatment group $(6 \times 8=48)$ were weighed and slaughtered. One bird representing the average body weight of each replication $(+/-10 \%)$ was selected for slaughter. Carcasses were chilled at $4^{\circ} \mathrm{C}$ for approximately 18 hours, and dissected. The weights of the breast, thigh, drumstick, giblets and abdominal fat were calculated relative (\%) to BW before slaughter. After $24 \mathrm{~h}$ of carcass chilling, the $\mathrm{pH}$ and color parameters of Pectoralis major subsamples were determined. The $\mathrm{pH}$ of breast muscle was measured $24 \mathrm{~h}$ post mortem directly in the left muscle of 
each turkey (Testo GmbH 206-pH2 meter, Wien, Austria). Meat color parameters L*, $a^{*}, b^{*}$ of each turkey were measured in the CIE LAB system (CIE, 1978), three times, by the reflectance method, with the HunterLab MiniScan XE Plus colorimeter (Hunter Associates Laboratory Inc., Reston, VA, USA), at different points over the muscle cross-section area, with standard illuminant $\mathrm{D}_{65}$ and $10^{\circ}$ standard observer angle. Before each session, the device was standardized using black and white standard plates.

\section{Chemical and biochemical analyses of meat}

The proximate chemical composition of breast meat was determined. Breast muscles were chilled at $4^{\circ} \mathrm{C}$, put through a laboratory mincer with a $2 \mathrm{~mm}$ mesh, and homogenized. Analytical samples of meat were collected to determine water, protein and fat content by standard methods (AOAC, 2005). The following redox status indicators were determined in breast meat homogenates: activities of superoxide dismutase (SOD) and glutathione peroxidase (GPx) - with the use of Ransel and Ransod diagnostic kits (Randox), vitamin C concentrations - according to Omaye et al. (1979), catalase (CAT) activity - according to Aebi (1984), concentrations of lipid hydroperoxidases (LOOH) - according to Sodergren et al. (1998), and concentrations of malondialdehyde (MDA) - according to Salih et al. (1987).

\section{Histopathological analysis}

During necropsy, pectoral muscles of each turkey were fixed in $10 \%$ neutralized formalin and embedded in paraffin blocks. Paraffin sections of the muscles $(5 \mu \mathrm{m})$ were stained with hematoxylin and eosin (HE). Each section was imaged using the Panoramic MIDI scanner (3DHISTECH, Hungary). A microscopic evaluation was conducted separately by two experienced pathologists. Photographs were taken and muscle fiber diameters were measured using Panoramic Viewer software (3DHISTECH, Hungary). A minimum of 100 fibers were counted in each muscle section in each group.

\section{Statistical analysis}

Two-way ANOVA was performed (the effects of Met dosage and source were analyzed). The statistical analysis included the determination of the characteristics of the analyzed traits (arithmetic means and SEM) and the significance of differences in mean values between source groups by Duncan's D test. The research hypothesis was verified with regard to histopathological changes by a chi-squared test (significant at $\mathrm{P} \leq 0.05$ ). Computations were performed using STATISTICA 10.0 software (StatSoft Inc. 2011).

\section{Results}

The Met content of diets administered to turkeys in successive 4-week periods, determined analytically (Table 2), was similar when different Met sources were used (DLM, LM and MHA) and different when Met was added at two levels: corresponding to that recommended by NRC (1994) and increased by approximately $50 \%$ ( $\mathrm{L}$ and $\mathrm{H}$, respectively). 


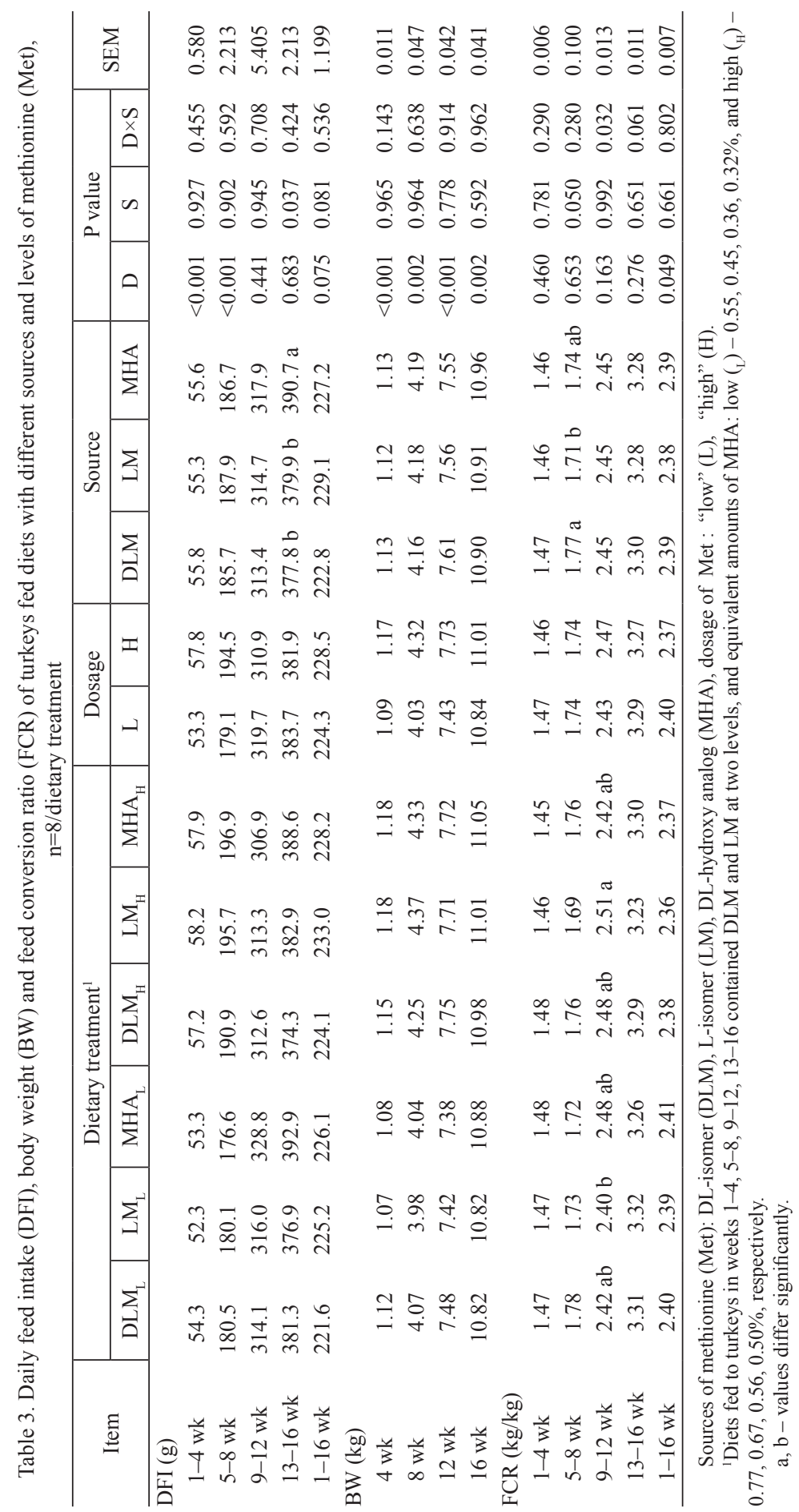




\section{Growth performance}

In two initial stages of rearing, until 8 weeks of age, daily feed intake (DFI) was higher in turkeys fed diets with the higher Met level $(\mathrm{P}<0.001)$, whereas in the later stages, DFI was not affected by dietary Met concentrations. The effect of Met source on DFI was noted only from 13 to 16 weeks of age $(\mathrm{P}=0.037$; Table 3 ). The higher Met level increased the BW of birds at all dates of weighing (4 and 12 wk, $\mathrm{P}<0.001 ; 8$ and $16 \mathrm{wk}, \mathrm{P}=0.002)$, and contributed to lower $\mathrm{FCR}$ values over the entire experimental period ( $1-16 \mathrm{wk}, \mathrm{P}=0.049)$. Met source had no effect on the BW of birds, whereas differences in FCR were noted only from 5 to 8 weeks of age, when FCR values were higher in groups fed DLM-supplemented diets, compared with LM-supplemented diets $(\mathrm{P}=0.050)$. Between 9 and 12 weeks of age, a $\mathrm{D} \times \mathrm{S}$ interaction was noted $(\mathrm{P}=0.032)$ : the higher level of $\mathrm{LM}$ increased FCR.

\section{Carcass yield and quality}

Neither dietary Met level nor source affected carcass dressing percentage, which ranged from $81.4 \%$ in treatment $\mathrm{DLM}_{\mathrm{H}}$ to $81.9 \%$ in treatment $\mathrm{LM}_{\mathrm{H}}$ (Table 4). The higher dietary Met level decreased the percentage of drumstick muscles in the total $\mathrm{BW}$ of turkeys $(\mathrm{P}=0.034)$. A $\mathrm{D} \times \mathrm{S}$ interaction $(\mathrm{P}=0.012)$ was noted for thigh muscles: the percentage of thigh muscles in the total BW of birds varied in groups fed DLM-supplemented diets. A similar trend was observed in drumstick muscles. Both the combined percentage of leg and breast muscles, and the percentage of breast muscle in the carcass were comparable in all dietary treatments. Dietary Met levels had no influence on carcass fat content. Turkeys fed diets with MHA had higher abdominal fat content, in comparison with birds fed diets with the remaining Met sources $(\mathrm{P}=0.017)$. The experimental factors had no effect on the relative weights of the gizzard and heart, whereas increased dietary Met content reduced the relative weight of the liver ( $\mathrm{P}=0.003$; Table 4$)$, regardless of Met source.

\section{Physicochemical properties of meat}

Among the analyzed parameters of the chemical composition of breast muscles, only dry matter (DM) content was affected by Met levels and sources (Table 5). The meat of turkeys fed diets supplemented with LM had higher DM content than the meat of turkeys fed diets supplemented with MHA $(\mathrm{P}=0.018)$, but the higher dietary level of $\mathrm{LM}$ decreased $\mathrm{DM}$ content $(\mathrm{D} \times \mathrm{S}$ interaction, $\mathrm{P}=0.002)$. A decrease was noted in the redness of breast muscle $\left(\mathrm{a}^{*}, \mathrm{P}=0.040\right)$ and active acidity measured $24 \mathrm{~h}$ post mortem $\left(\mathrm{pH}_{24 \mathrm{~h}} ; \mathrm{P}=0.028\right)$ with increasing dietary Met levels. Met levels and sources had no influence on the remaining components of meat color ( $\mathrm{L}^{*}$ and $\mathrm{b}^{*}$ ). Fiber diameter in the Pectoralis major muscle was smaller in turkeys fed diets with the higher dietary Met level (irrespective of Met source) than in birds receiving diets supplemented with Met at the level that matched NRC recommendations (1994; $\mathrm{P}=0.004)$. 


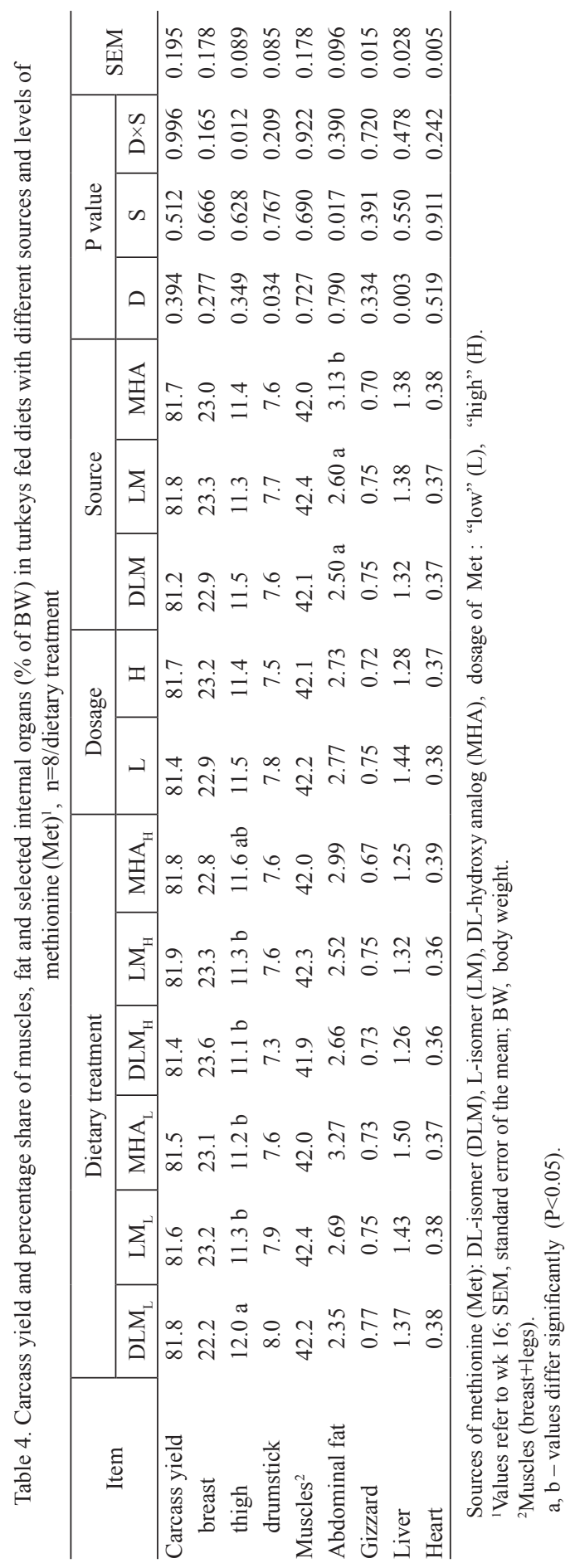




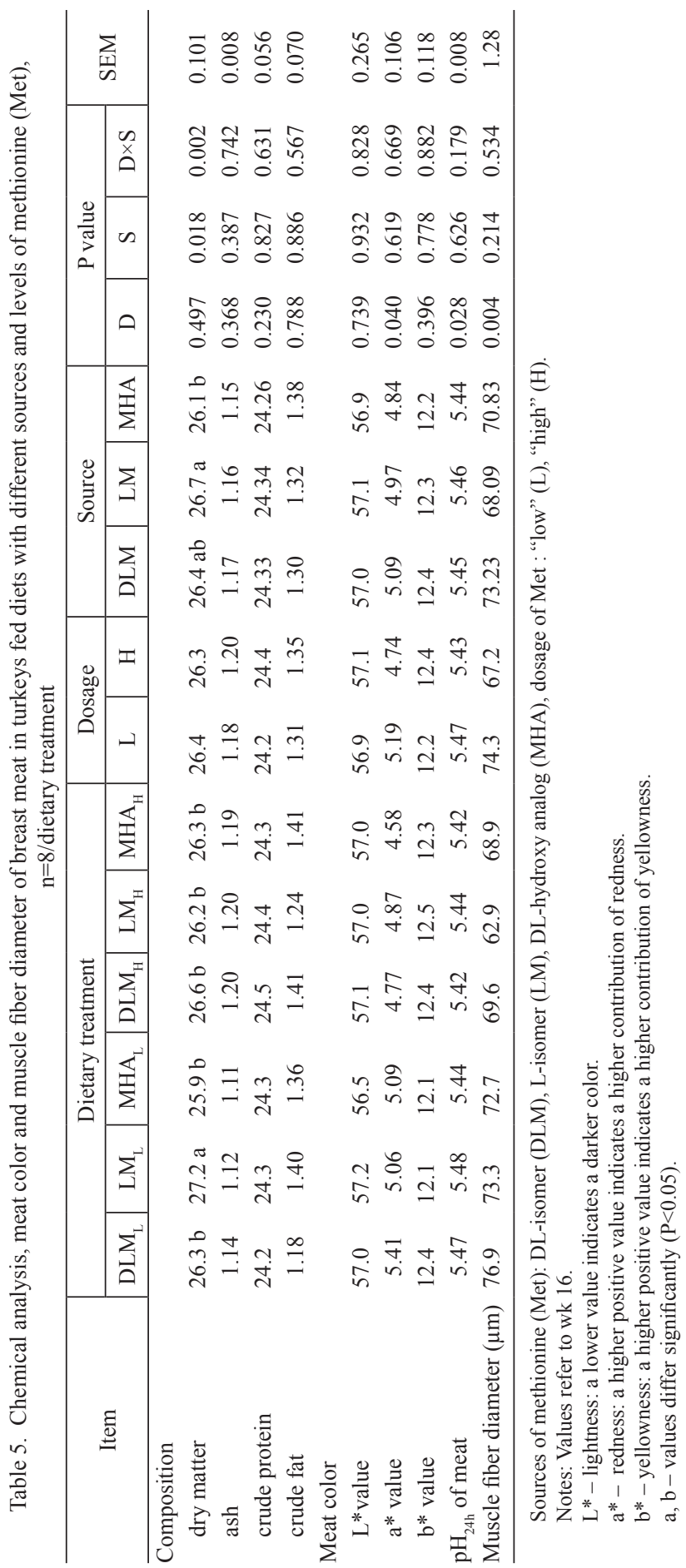




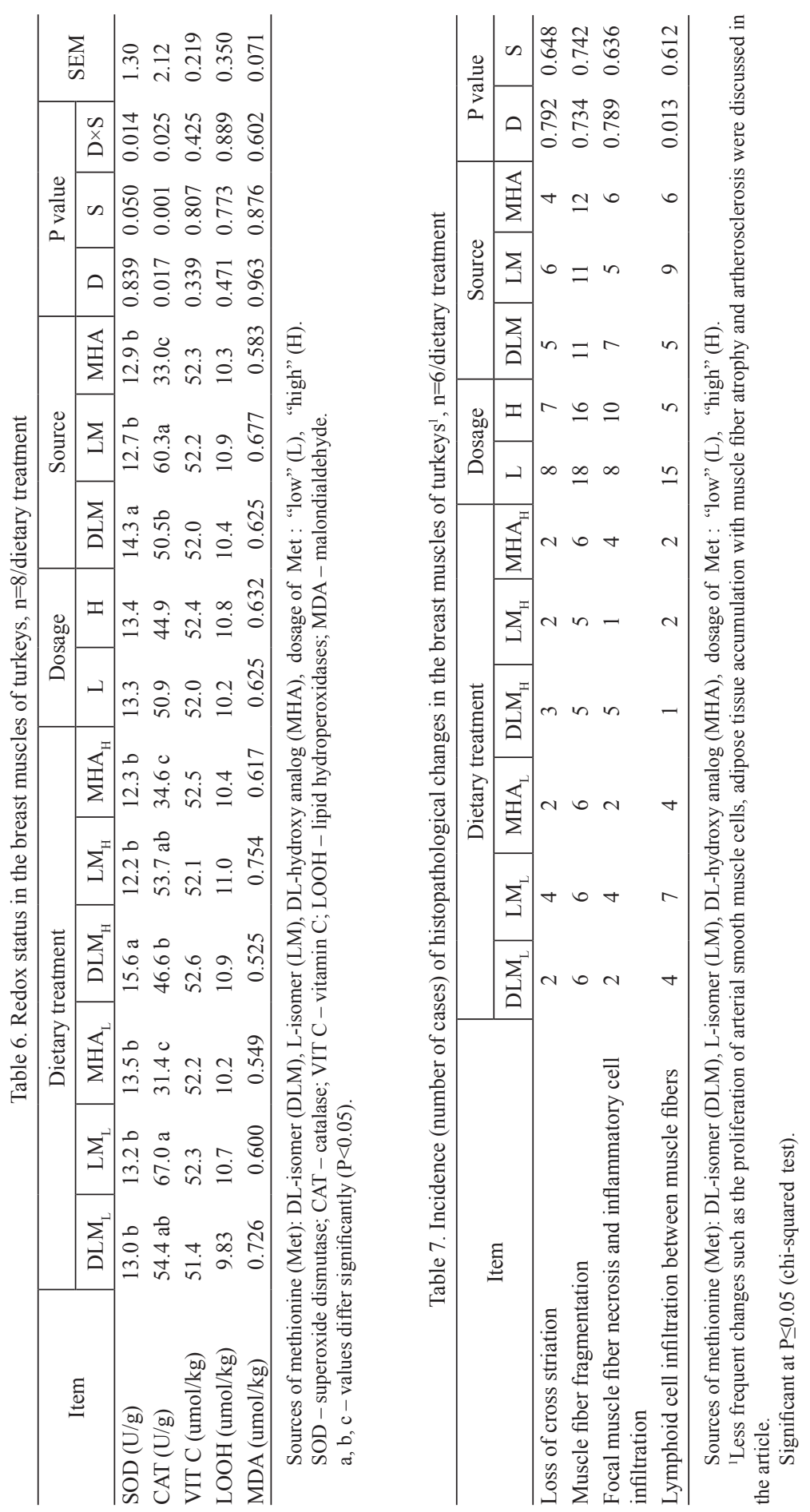




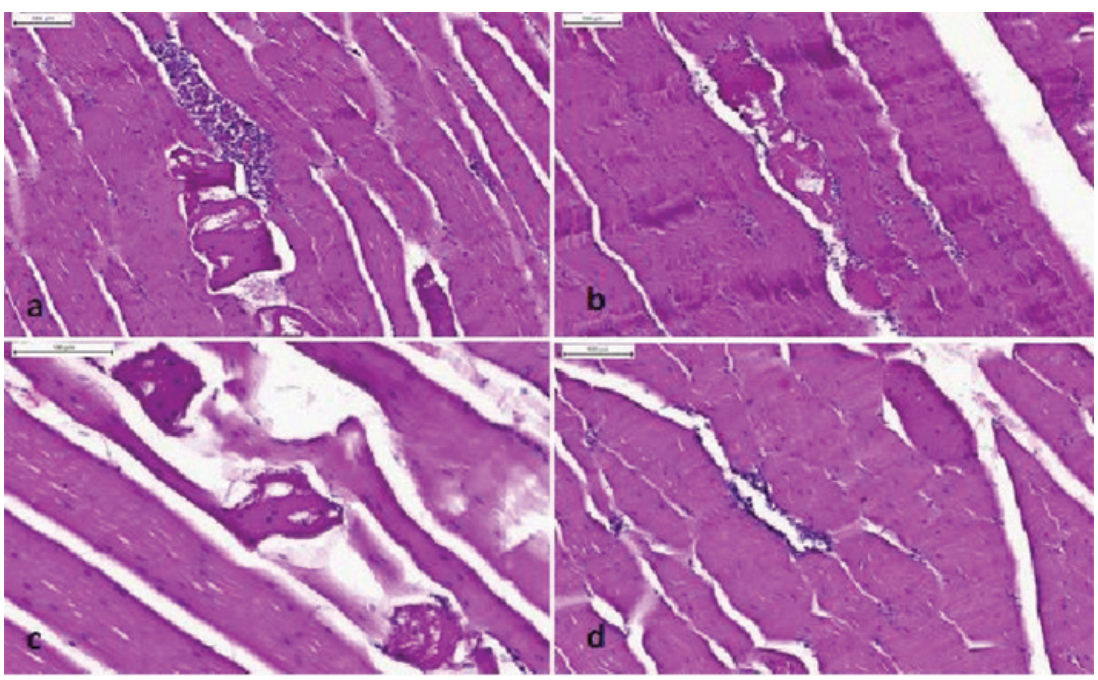

a) muscle fiber fragmentation; focal muscle fiber necrosis and inflammatory cell infiltration. HE

b) muscle fiber fragmentation; focal muscle fiber necrosis

c) muscle fiber fragmentation. HE

d) lymphoid cell infiltration between fibers. HE

Figure 1. Histopathological changes in the breast muscles of turkeys (HE - hematoxylin and eosin staining)

\section{Redox status and histopathological changes in breast muscles}

Among the analyzed parameters of the redox status in turkey breast meat, the concentrations of vitamin $\mathrm{C}$, lipid hydroperoxidases (LOOH) and MDA were similar in all dietary treatments regardless of Met levels and sources, whereas the activities of SOD and CAT varied (Table 6). Higher SOD activity was observed in turkeys fed diets with DLM $(\mathrm{P}=0.050)$, and a $\mathrm{D} \times \mathrm{S}$ interaction was noted in treatment $\mathrm{DLM}_{\mathrm{H}}(\mathrm{P}=0.014)$. The higher dietary Met level decreased CAT activity (44.9 vs. 50.9; $\mathrm{P}=0.017$ ), and Met sources had the following effect on CAT activity: LM > DLM $>$ MHA. Dietary supplementation with LM at the higher level decreased CAT activity $(\mathrm{D} \times \mathrm{S}$ interaction; $\mathrm{P}=0.025$ ), whereas the levels of $\mathrm{DLM}$ and MHA had no effect on CAT activity. A histopathological analysis revealed numerous changes in the breast muscle, such as the loss of cross striation, fiber fragmentation, focal fiber necrosis and inflammatory cell infiltration, and lymphoid cell infiltration between fibers. Those histopathological changes are illustrated in Figure 1, and their incidence is shown in Table 7. The incidence of lymphoid cell infiltration between fibers in the Pectoralis major muscle was three-fold higher in turkeys fed diets with lower Met content $(\mathrm{P}=0.013)$. Other histopathological changes, including the proliferation of arterial smooth muscle cells, adipose tissue accumulation with muscle fiber atrophy and artherosclerosis, were noted sporadically - in 5, 2 and 2 samples, respectively, of the 48 analyzed breast muscle samples (data not shown). 


\section{Discussion}

\section{Growth performance}

Kubińska et al. (2015) demonstrated that diets without pure supplemental Met, whose Met content was lower than that recommended by NRC (1994), decreased the BWG of turkeys during the first 8 weeks, but exerted no significant effect on BWG when fed from 9 weeks of age (Jankowski et al., 2017). Recent experiments performed on turkeys (Kubińska et al., 2015, 2016; Jankowski et al., 2017) have demonstrated that high dietary Met content, increased by around $50 \%$ above the NRC-recommended level (1994), has no significant effect on growth performance parameters. In the cited studies, where the period of Met feeding was shorter ( $8 \mathrm{wk}$ ), increased dietary Met content did not increase the body weight gain (BWG) of turkeys. In the complete turkey production cycle, analyzed in this experiment, the higher dietary Met level increased the final BW of birds and decreased FCR, in comparison with the lower Met level that corresponded to NRC recommendations (1994). In a study by Lemme et al. (2005), diets with graded Met levels, at $90 \%, 100 \%$ and $120 \%$ of BUT (2000) recommendations, led to a linear increase in the BWG of turkeys from 36 to 63 days of age. Unlike in previous studies (Gonzales-Esquerra et al., 2007) investigating diets supplemented with DLM and MHA, in our experiment Met sources had no influence on the BW of turkeys or FCR values.

\section{Carcass yield and quality}

The efficiency of poultry meat production is largely determined by the carcass and meat yields of birds (Murawska, 2013; Murawska et al., 2015). In the present experiment, carcass dressing percentage was comparable in all groups and similar to that reported in other studies (Jankowski et al., 2016). The higher dietary Met level did not increase the relative weight of breast muscle in turkey hens, which is consistent with previous findings (Jankowski et al., 2016). Such an effect was observed in an experiment performed on broiler chickens (Zhai et al., 2012). Liu et al. (2010) demonstrated that adequate dietary Met levels are required to increase lean carcass content and reduce abdominal fat deposition in broilers. The results of this study and a similar experiment conducted by Jankowski et al. (2016) did not confirm the effect of dietary Met levels on the abdominal fat content of the carcass. Our findings show that turkey diets with Met content exceeding NRC (1994) recommendations by approximately $50 \%$ do not induce significant changes in carcass quality.

\section{Physicochemical properties of meat}

In the present study, the breast muscles of turkeys fed diets with different Met levels were characterized by similar values of color lightness ( $\left.\mathrm{L}^{*}\right)$ and yellowness $\left(b^{*}\right)$, whereas redness $\left(a^{*}\right)$ values were lower in the meat of birds receiving diets with higher Met content. According to Wang et al. (2009), increased dietary Met levels may contribute to meat color stabilization due to decreased protein oxidation. Albrecht et al. (2017) demonstrated that Met supplementation had a significant influence on the quality parameters of chicken meat during storage. Dietary Met 
levels, regardless of its source, affected the quality parameters of breast muscles in broilers. According to other authors (Jiao et al., 2010; Wu et al., 2011), a rapid increase in BW, also resulting from increased Met inclusion rates, leads to changes in meat color. Such a correlation was noted in our experiment and in a study by Jankowski et al. (2016) where increased dietary Met content caused a linear decrease in redness $\left(\mathrm{a}^{*}\right)$ in turkey breast meat. Other authors (Damaziak et al., 2016; Yost et al., 2002) demonstrated that in turkeys, a fast growth rate may reduce glycogen levels in muscles, adversely affecting glycolysis and, consequently, meat $\mathrm{pH}$. In an experiment by Jankowski et al. (2016), higher dietary Met content, close to BUT. (2012) recommendations, increased the $\mathrm{pH}_{24}$ of breast meat in comparison with birds fed diets with Met levels that matched NRC (1994) recommendations. In our study, the higher dietary Met level decreased $\mathrm{pH}_{24}$ values regardless of Met source. In the present experiment, fiber diameter in the Pectoralis major muscle was not influenced by Met source, and it was smaller in turkeys fed diets with higher Met content, which could affect meat $\mathrm{pH}$. A correlation between fiber diameter and $\mathrm{pH}_{24}$ values in the Pectoralis major muscle was observed by Marcu et al. (2013) in broiler chickens.

\section{Redox status and histopathological changes in breast muscles}

Experiments involving broiler chickens (Chen et al., 2013; Shen et al., 2015) indicate that increased dietary Met levels improve the antioxidant protection of the body mainly by increasing glutathione concentrations in the liver. Experiments performed on young turkeys (Kubińska et al., 2016) suggest that diets supplemented with Met at levels that matched or were slightly lower than BUT (2012) recommendations exerted antioxidant effects, whereas diets with higher Met concentrations could have pro-oxidative effects. In the present study, increased dietary Met content did not induce changes in the main indicators of the redox status of turkey breast meat, such as the concentrations of MDA and LOOH. An increase in CAT activity, which is associated with advanced lipid peroxidation (Surai, 2016), was noted in turkeys fed diets with higher Met content. Differences in the activities of SOD (which was higher in turkeys fed DLM-supplemented diets) and CAT (LM > DLM > MHA) were not accompanied by differences in the concentrations of MDA and LOOH in meat. In the light of previous findings (Sosnicki and Wilson, 1991), the histopathological changes in the Pectoralis major muscle noted in our study, in particular the loss of cross striation, fiber fragmentation, focal fiber necrosis and inflammatory cell infiltration, are typical of turkeys selected for rapid growth. In a study by Velleman et al. (2003), turkeys selected for increased BW had hypercontracted muscle fibers at 16 weeks of age, and significant fragmentation of fiber bundles was observed throughout the Pectoralis major muscle at 20 weeks of age. The cited authors found that reduced capillary blood supply decreased $\mathrm{pH}$ and led to muscle damage. Apart from the incidence of lymphoid cell infiltration between the fibers of Pectoralis major muscle, dietary Met levels and sources had no influence on the incidence or type of histopathological changes. In the present study, histopathological changes were noted in a relatively high number of birds, but their extent was limited. 


\section{Conclusions}

Increased dietary Met content, approximately 50\% higher than that recommended by NRC (1994), regardless of Met source, resulted in a higher final BW of birds, but it did not improve carcass or meat quality. The higher dietary Met level caused a deterioration in selected parameters of meat quality, including a decrease in $\mathrm{pH}_{24}$ and a lower contribution of redness, it had no influence on the redox status of meat, and reduced muscle fiber diameter. Apart from a lower incidence of lymphoid cell infiltration between the fibers of Pectoralis major muscle, the higher dietary Met level had no influence on the incidence or type of histopathological changes. Throughout the experiment, no significant differences were noted in the growth performance parameters of turkeys, irrespective of Met source. MHA contributed to higher abdominal fat content, lower dry matter content and lower CAT activity in breast meat, compared with DLM and LM.

\section{References}

A e b i H. (1984). Catalase in vitro. Meth. Enzymol., 105: 121-126.

Albrecht A., Herbert U., Miskel D., Heinemann C., Braun C., Dohlen S., Zeitz J.O., Eder K., S aremi B., Kreyen s chmidt J. (2017). Effect of methionine supplementation in chicken feed on the quality and shelf life of fresh poultry meat. Poultry Sci., 96: 2853-28611.

British United Turkeys Ltd (BUT) (2012). Commercial performance goals. 5th ed. Broughton, Chester, UK: Warren Hall. http://www.aviagen.com/home.aspx?siteId=8 (accessed 22.11.2012).

Chen Y.P., Chen X., Zhang H., Z h o u Y.M. (2013). Effects of dietary concentrations of methionine on growth performance and oxidative status of broiler chickens with different hatching weight. Brit. Poultry Sci., 54: 531-537.

CIE (1978). Recommendations on uniform color spaces-color difference equations. Psychometric Color Terms. Supplement No. 2 to CIE Publication No. 15 (E-1.3.1), 1971/(TC-1-3), Commission internationale de l'éclairage. Paris.

Damaziak K., Pietrzak D., Michalczuk M., Adamczak L., Chmiel M., Florows ki T., Gozdowski D., Nie mie c J. (2016). Early and 24 h post-mortem changes in breast muscle quality traits of two turkey genotypes and their reciprocal crosses raised under semi-confined conditions. Brit. Poultry Sci., 5: 51-62.

Drażbo A., Kozłowski K., Chwastows ka-Siwiecka I., S obczak A., Kwiatkows k i P., L e m m e A. (2015). Effect of different dietary levels of DL-methionine and the calcium salt of DL-2-hydroxy-4-(methyl) butanoic acid on the growth performance, carcass yield and meat quality of broiler chickens. Europ. Poultry Sci., 79: DOI:10.1399/eps.2015.114.

Gonzales-Esquerra R., Vázquez-Añón M., Hampton T., York Feine T., Wue lling C., Knight C. (2007). Evidence of a different dose response in turkeys when fed 2-hydroxy-4(methylthio) butanoic acid versus DL-methionine. Poultry Sci., 86: 517-524.

Havenste in G.B., Ferket P.R., Grimes J.L., Qureshi M.A., N es tor K.E. (2007). Comparison of the performance of 1966-versus 2003-type turkeys when fed representative 1966 and 2003 turkey diets: Growth rate, livability, and feed conversion. Poultry Sci., 86: 232-240.

Hybrid Turkeys (2014). A Hendrix Genetics. https://www.hybridturkeys.com/en/ (accessed 16.12.2014).

J a n k ow s ki J., K u b in sk a M., Z d unc z y k Z. (2014). Nutritional and immunomodulatory function of methionine in poultry diets - a review. Ann Anim. Sci., 14: 17-31.

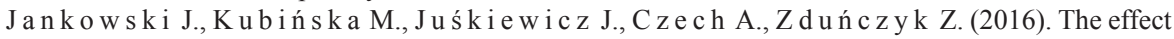
of dietary methionine on fattening performance and selected blood and tissue parameters of turkeys. Arch. Anim. Nutr., 70: 127-140. 
Jankowski J., Kubińska M., Juśkiewicz J., Czech A., Ognik K., Zduńczyk Z. (2017). Effect of different dietary methionine levels on the growth performance and tissue redox parameters of turkeys. Poultry Sci., 96: 1235-1243.

Ji a o P., Guo Y., Yang X., Long F. (2010). Effects of dietary arginine and methionine levels on broiler carcass traits and meat quality. J. Anim. Vet. Adv., 9: 1546-1551.

Kubińska M., Tykałowski B., Koncicki A., Jankowski J. (2015). Biochemical and immunological responses of young turkeys to vaccination against Ornithobacterium rhinotraheale and different levels of dietary methionine. Pol. J. Vet. Sci., 18: 807-816.

Kubińska M., Jankowski J., Juśkiewicz J., Ognik K., Czech A., Celej J., Zduń c zy k Z. (2016). Growth rate and metabolic parameters in young turkeys fed diets with different inclusion levels of methionine. J. Anim. Feed Sci., 25: 152-159.

Lemme A., Kozłowski K., Jankowski J., Petr A., Zduńczyk Z. (2005). Responses of 36- to 63-day-old BUT Big 6 turkey toms to graded dietary methionine+cysteine levels. J. Anim. Feed Sci., 14: 467-470.

L i u G.Q., Z ong K., Zhang L.L., C a o S.Q. (2010). Dietary methionine affect meat quality and myostatin gene exon 1 region methylation in skeletal muscle tissue of broilers. Agr. Sci. China., 9: 1338-1346.

Marcu A., Vacaru-Opriş I., Dumitrescu G., Marcu A., Petculescu Ciochină L., N i cula M., Dronc a D., Ke lc i ov B. (2013). Effect of diets with different energy and protein levels on breast muscle characteristics of broiler chickens. Sci. Pap. Anim. Sci. Biotechnol., 46: 333-340.

Muraws k a D. (2013). Age-related changes in the percentage content of edible and non-edible components in turkeys. Poultry Sci., 92: 255-264.

Murawska D., Kozłowski K., Tomaszewska K., Brzozowski W., Zawacka M., Michalik D. (2015). Age-related changes in the tissue composition of carcass parts and in the distribution of lean meat, fat with skin and bones in turkey carcasses. Europ. Poultry Sci., 79; DOI: $10.1399 /$ eps.2015.103.

NRC (1994). Nutrient Requirements of Poultry. 9th rev. ed. Natl. Acad. Press, Washington, DC, US.

O ma ye S.T., Tumbull J.D., S a uberlich H.E. (1979). Selected methods for determination of ascorbic acid in animal cells, tissues and fluids. Meth. Enzymol., 62: 3-11.

Park I., Pasquetti T.J., Malheiros R.D., Zheng L., Ferket P., K im S.W. (2016). Effect of grade L-methionine on intestinal redox status, intestinal development, and growth performance of turkey poults compared with conventional DL-methionine. In: Proceedings of the ADSA-ASAS Midwest Meeting, Des Moines, IA, Nonruminant I, No 199. https://asas.confex.com/asas/mw16/ webprogram/Paper13318.html.

S a li h M., S m ith D.M., Pric e J.F., D aw s on L.E. (1987). Modified extraction 2-thiobarbituric acid method for measuring lipid oxidation in poultry. Poultry Sci., 66: 1483-1488.

Shen Y.B., Ferket P., Park I., Malheiros R.D., Kim S.W. (2015). Effects of feed grade Lmethionine on intestinal redox status, intestinal development, and growth performance of young chickens compared with conventional DL-methionine. J. Anim. Sci., 93: 2977-2986.

Sodergren E., Nourooz-Zadeh J., Berglund L., Vessby B. (1998). Re-evaluation of the ferrous oxidation in xylenol orange assay for the measurement of plasma lipid hydroperoxides. J. Biochem. Biophys. Methods., 37: 37-146.

S o s nicki A.A., Wils o n B.W. (1991). Pathology of turkey skeletal muscle: Implications for the poultry industry. Food Struct., 10: 317-326.

S u r a i P.F. (2016). Antioxidant systems in poultry biology: superoxide dismutase. iMedPub Journals, 1: 1-8. http://animalnutrition.imedpub.com.

Swennen Q., Geraert P.A., Mercier Y., Everaert N., S tinckens A., Willems en H., Li Y., Decuypere E., Buys e J. (2011). Effects of dietary protein content and 2-hydroxy4-methylthiobutanoic acid or DL-methionine supplementation on performance and oxidative status of broiler chickens. Br. J. Nutr., 106: 1845-1854.

Velle m a n S.G., A n der s on J.W., C o y C.S., N e s t or K.E. (2003). Effect of selection for growth rate on muscle damage during turkey breast muscle development. Poultry Sci., 82: 1069-1074.

Wang Z.G., P a n X.J., P en g Z.Q., Z h a o R.Q., Z h o u G.H. (2009). Methionine and selenium yeast supplementation of the maternal diets affects color, water-holding capacity, and oxidative stability of their male offspring meat at the early stage. Poultry Sci., 88: 1096-1101. 
Willke T. (2014). Methionine production - a critical review. Appl. Microbiol. Biotechnol., 98: 9893-9914.

W u D.J., P a n X.J., Wang Z.G., P eng Z.Q., Zh a o L.Y., Z hang Y.W. (2011). Effect of maternal selenium and methionine on poultry products (egg and meat) qualities and oxidative stability, in: Soybean and Nutrition, El-Shemy H. (Ed.). E-publishing InTech, Rijeka, Croatia, pp. 269-288.

Yo s t J.K., K e n n y P.B., S li d e r S.D., R u s s ell R.W., Kill e f e r J. (2002). Influence of selection for breast muscle mass on myosin isoform composition and metabolism of deep pectoralis muscles of male and female turkeys. Poultry Sci., 81: 911-917.

Zhai W., Arauj L.F., Burges S.C., Cookse A.M., Pendarvis K., Mercie Y., Corzo A. (2012). Protein expression in pectoral skeletal muscle of chickens as influenced by dietary methionine. Poultry Sci., 91: 2548-2555.

Received: 5 X 2017

Accepted: 24 I 2018 